\title{
Aerosol and bioaerosol particle size and dynamics from defective sanitary
}

\section{plumbing systems}

${ }^{1}$ Institute for Sustainable Building Design, Heriot-Watt University, Edinburgh,EH14 4AS UK

\section{Abstract}

Aerosols are readily transported on airstreams through building sanitary plumbing and sewer systems and those containing microbial pathogens (known as bioaerosols) are recognised as contributors to infection spread within buildings. When a defect occurs in the sanitary plumbing system that affects the system integrity, a cross-transmission route is created that can enable the emission of bioaerosols from the system into the building. These emission occurrences are characterised as short-burst events (typically $<1$ minute in duration) which makes them difficult to detect and predict. The characterisation of these emission events is the focus of this research.

Two methods were used to characterise bioaerosol emission events in a full scale test rig : (i) an Aerodynamic Particle Sizer (APS) for particle size distribution and concentrations; and (ii)

21 a slit-to-agar sampler to enumerate the ingress of a viable tracer microorganism (Pseudomonas putida). The APS data confirmed that most particles (> 99.5\%) were $<5 \mu \mathrm{m}$ and were therefore considered aerosols. Particles generated within the sanitary plumbing system as a result of a toilet flush leads to emissions into the building during system defect conditions with an 
medRxiv preprint doi: https://doi.org/10.1101/2020.11.01.20223974; this version posted November 4, 2020. The copyright holder for this preprint (which was not certified by peer review) is the author/funder, who has granted medRxiv a license to display the preprint in

All rights reserved. No reuse allowed without permission.

detected of a size $>11 \mu \mathrm{m}$ anywhere in the system. Particle count was influenced by flush volume, but it was not possible to determine if there was any direct influence from airflow rate. Typical emissions resulting from a 6 litre flush were in the range of $280-400$ particles per second at a concentration of typically 9 to 12 number per $\mathrm{cm}^{3}$ and a total particle count in the region of 3,000 to 4,000 particles, whereas the peak emissions from a 1.2 litre flush was 60 - 80 particles per second at a concentration of 2.4 to 3 number per $\mathrm{cm}^{3}$ and a total particle count in the region of 886 to 1045 particles. The reduction in particles is in direct proportion to the reduction in flush volume. The slit-to-agar sampler was able to provide viable time course CFU data and confirmed the origin of the particles to be the tracer microorganism flushed into the system. The time course data also has characteristics consistent with the unsteady nature of a toilet flush.

\section{KEYWORDS}

bioaerosols, aerosols, SARS-CoV-2, COVID-19, WC flush, slit-to-agar sampling, transient fluid flow, aerodynamic particle sizing.

\section{INTRODUCTION}

\subsection{Background}

The mechanism of airborne transmission of the SARS-CoV-2 virus, specifically the transport of virus-laden particles (bioaerosols) in the air, has been a source of much debate since the virus was first identified in Wuhan, China, in December $2019^{1}$. The rapid spread of the SARS-CoV2 virus around the world has caused a global coronavirus disease (COVID-19) pandemic. 
medRxiv preprint doi: https://doi.org/10.1101/2020.11.01.20223974; this version posted November 4, 2020. The copyright holder for this preprint (which was not certified by peer review) is the author/funder, who has granted medRxiv a license to display the preprint in All rights reserved. No perpetuity.

52 Most of the focus on how the SARS-CoV-2 virus is transmitted has concentrated on human-tohuman transmission. This is largely due to a general lack of knowledge of how infections spread $^{2}$. Generally, viral respiratory infections are considered to be spread by direct contact, by touching an infected person or the surfaces and other fomites that the infected person has touched ${ }^{3}$. Bioaerosols expelled by the infected person can land on surfaces where the virus can remain stable for days ${ }^{4}$. Droplets can also be deposited directly onto a person in close proximity to the infected person. It is on this basis that frequent hand-washing and maintaining social distance are considered the main precautions against contracting infection. The transmission route which is less well understood, and often overlooked, is the transport of the virus in the air as bioaerosols, which can be so small that they can travel long distances within airstreams.

Generally, droplets are referred to as particles with a diameter $>5 \mu \mathrm{m}$ that fall rapidly to the ground under gravity, and so are transmitted only over a limited distance (e.g. $\leq 1 \mathrm{~m}$ ), see Table 1. Aerosols, on the other hand, are particles with a diameter $\leq 5 \mu \mathrm{m}$ that can remain suspended in the air for significant periods of time, allowing them to be transmitted over longer distances $>1 \mathrm{~m}^{5-7}$ Bioaerosols is the term used to define aerosols that contain viruses, bacteria, fungi, or bacteria and fungi cell components ${ }^{8}$. They can also contain pollen grains or other biological material.

Table 1: Definitions and characteristics of particles of different sizes

\begin{tabular}{llll}
\hline Particle & Size & Reach & Characteristic \\
\hline Droplet & $>5 \mu \mathrm{m}$ & $\leq 1 \mathrm{~m}$ & $\begin{array}{l}\text { Can be deposited on surfaces and fomites. Can contain } \\
\text { respiratory pathogens. }\end{array}$ \\
\hline Aerosol & $\leq 5 \mu \mathrm{m}$ & $>1 \mathrm{~m}$ & $\begin{array}{l}\text { Can be transported in airstreams and remain persistent in } \\
\text { the air for long time periods. Can be inhaled. }\end{array}$ \\
\hline Bioaerosol & $\leq 5 \mu \mathrm{m}$ & $>1 \mathrm{~m}$ & $\begin{array}{l}\text { An aerosol that contains respiratory allergens or pathogens. } \\
\text { Can be transported in airstreams and remain persistent in } \\
\text { the air for long time periods. Can be inhaled. }\end{array}$ \\
\hline
\end{tabular}


medRxiv preprint doi: https://doi.org/10.1101/2020.11.01.20223974; this version posted November 4, 2020. The copyright holder for this preprint (which was not certified by peer review) is the author/funder, who has granted medRxiv a license to display the preprint in All rights reserved. No perpetuity.

73 The research presented in this paper investigates the aerosolisation of pathogens inside the 74 sanitary plumbing system and their transmission as bioaerosols into the building during system defect conditions. Literature on this topic is very sparse since most research to date has focused on the 'room side' rather than the 'sanitary plumbing side'. Work on flushing toilets Verani et al., Best et al., Johnson et al., Noble et al., Gebra et al., and Baker et al. ${ }^{9-11}$ all present compelling evidence on the role that a toilet flush can play in generating bioaerosols within the bathroom. Our research differs from those cited in that it focuses on the aerosolisation process that occurs inside the sanitary plumbing system following wastewater discharge into the system, and the subsequent emission of aerosols (specifically bioaerosols) into the building through defects that can occur within the U-bend trap seal due to evaporation or the propagation of high pressure air surges inside the sanitary plumbing system ${ }^{12}$. This is particularly relevant in tall buildings where sanitary plumbing system airflows and pressures can be relatively very high $13-16$.

The mechanism of aerosolisation within a sanitary plumbing system is due, in the main, to the unsteady discharge of wastewater into the system under normal usage. The surge waves generated as a result of these discharges play a large part in the aerosolisation process. One of the main surge generators within a sanitary plumbing system is the toilet. A 6 litre surge wave is typically generated with every flush and this interacts with the airflow and air pressures within the system to instigate aerosolisation. The characteristics of toilet flushes are well understood ${ }^{17}$. Figure 1 illustrates the mechanism of aerosol generation within the sanitary plumbing system during and following toilet flushing. 
medRxiv preprint doi: https://doi.org/10.1101/2020.11.01.20223974; this version posted November 4,2020 . The copyright holder for this preprint (which was not certified by peer review) is the author/funder, who has granted medRxiv a license to display the preprint in perpetuity.

All rights reserved. No reuse allowed without permission.

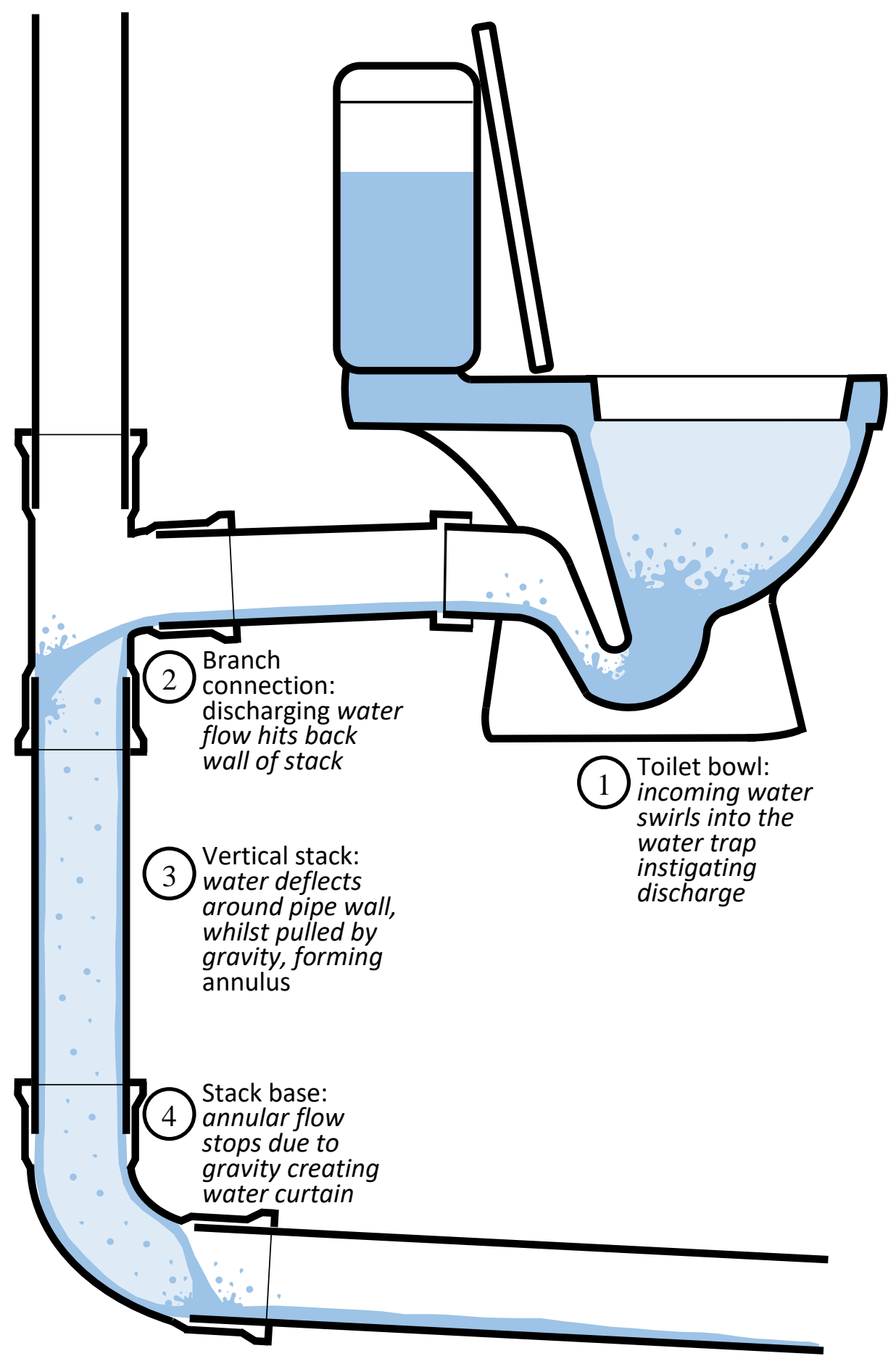


medRxiv preprint doi: https://doi.org/10.1101/2020.11.01.20223974; this version posted November 4, 2020. The copyright holder for this preprint (which was not certified by peer review) is the author/funder, who has granted medRxiv a license to display the preprint in

All rights reserved. No reuse allowed without permission.

102 Whilst greater evidence surrounding the prevalence and infectivity of SARS-CoV-2 in faeces

103 and wastewater is needed, the evidence is building and some studies have suggested that faeces

104 can contain viable virions ${ }^{18,19}$.

105

106 Recent work by Kang et al. ${ }^{20}$ reports a probable case of local transmission of SARS-CoV-2 via

107 defects within a building's sanitary plumbing system. The sanitary plumbing system has been

108 shown to be both a reservoir for pathogens ${ }^{21}$ and a cross-transmission route between different

109 areas within a building 22.

110

111 The ingress of bioaerosols into the building occurs following a pulsed air flow event. Such

112 pulses are instigated by the dynamic response of airflows within the sanitary plumbing system

113 to random sanitary appliance discharges. In experiments carried out by Gormley et al. (6), a

114 two storey sanitary plumbing system was built and the extent of contamination was established.

115 The pipe network, the airflows, the room surfaces, the room extract fan and associated ductwork

116 were all found to be contaminated due to a single toilet flush. The flush contained a culture of

117 Pseudomonas putida acting as a tracer organism.

119 Understanding these concepts has helped identify the source of specific outbreaks, notably the

120 SARS-CoV-1 outbreak in one particular apartment block in Hong Kong in $2003{ }^{23-26}$ where the

121 sanitary plumbing system was implicated in the spread of the virus.

123 Figure 2 provides a graphical representation of the main modes of disease transmission,

124 including the accepted human-to-human transmission under close contact, as well as the faecal-

125 oral transmission modes via the mechanisms of room-side toilet flushing, and the subsequent

126 system-side bioaerosol generation and ingress through a defective open trap. As studies have 
medRxiv preprint doi: https://doi.org/10.1101/2020.11.01.20223974; this version posted November 4, 2020. The copyright holder for this preprint (which was not certified by peer review) is the author/funder, who has granted medRxiv a license to display the preprint in

perpetuity.
All rights reserved. No reuse allowed without permission.

127 aimed to quantify and characterise the aerosol particle release from people when breathing,

128 talking, singing, coughing, etc., this research aims to quantify and characterise the aerosol

129 particle emissions from within a sanitary plumbing system following a toilet flush event.

130

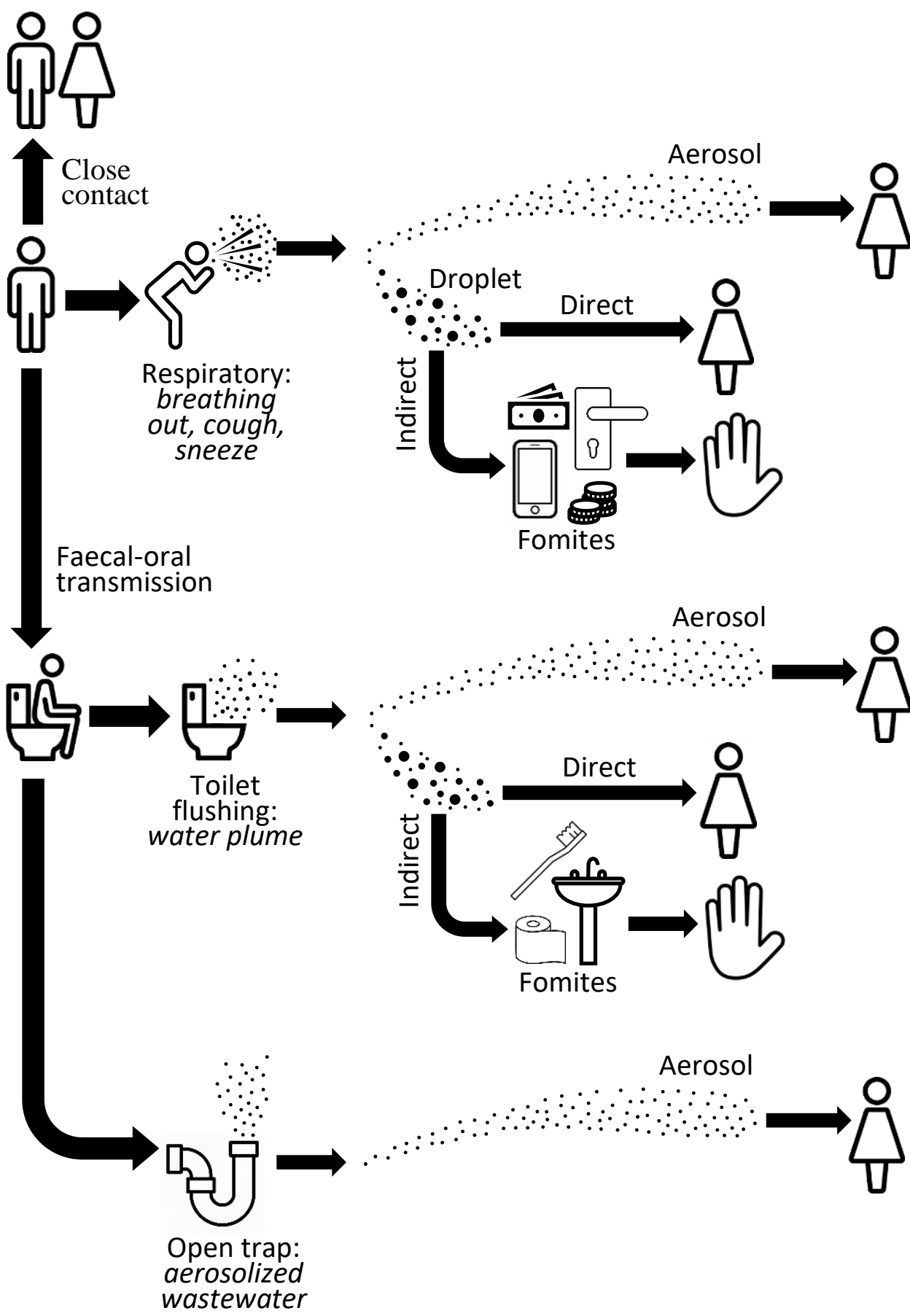

Figure 2: Aerosol generating mechanisms/processes and disease transmission routes within the 
medRxiv preprint doi: https://doi.org/10.1101/2020.11.01.20223974; this version posted November 4, 2020. The copyright holder for this preprint (which was not certified by peer review) is the author/funder, who has granted medRxiv a license to display the preprint in

All rights reserved. No reuse allowed without permission.

\subsection{Paper Structure}

Particle sizes, concentrations, and distributions are presented from the Aerodynamic Particle Sizer (APS) data. This represents what can be emitted into the building if there is a defect in the sanitary plumbing system. The intention is not to enumerate microorganisms in the air but to suggest the aerodynamic size of particles which leads to an understanding of what their impact might be on the transmission of contaminated air from the sanitary plumbing system into the building. The second dataset reported shows the timing and dynamics of aerosols emitted into the building via a defective U-bend trap seal having been generated following a simulated toilet flush which had been contaminated with a tracer organism, $P$. putida.

\section{MATERIALS/METHODS}

\subsection{Test Rig}

The test rig shown in Figure 3 was constructed in the Water Laboratory at Heriot-Watt University. The test rig is designed to European standards using EN12056:2000-2 ${ }^{27}$ and represents a two storey building sanitary plumbing system. The system simulates a toilet flush on Floor 1 and has a sealed test chamber on Floor 2 (to represent a bathroom). The test chamber has an extract fan with a length of flexible ducting attached. Instruments for analysis of aerosols and bioaerosols (see below) through the system were positioned at the end of the ducting.

The induced airflow in the system was set by a variable fan speed controller and the air velocity was measured by the anemometer in the pipework. To simulate a toilet flush, a pipe with a capacity to hold 6 litres of water (the maximum flush volume of a new toilet) was connected above a manual discharge valve. A 6 litre culture of $P$. putida, was inoculated into the drainage system via toilet flush and tracked at the outlet duct using the slit-to-agar sampler. The simulated 
medRxiv preprint doi: https://doi.org/10.1101/2020.11.01.20223974; this version posted November 4, 2020. The copyright holder for this preprint (which was not certified by peer review) is the author/funder, who has granted medRxiv a license to display the preprint in All rights reserved. No reuse allowed without permission.

161 toilet flush was initiated by opening the discharge valve, replicating the process in a normal

162 drop valve flush toilet.
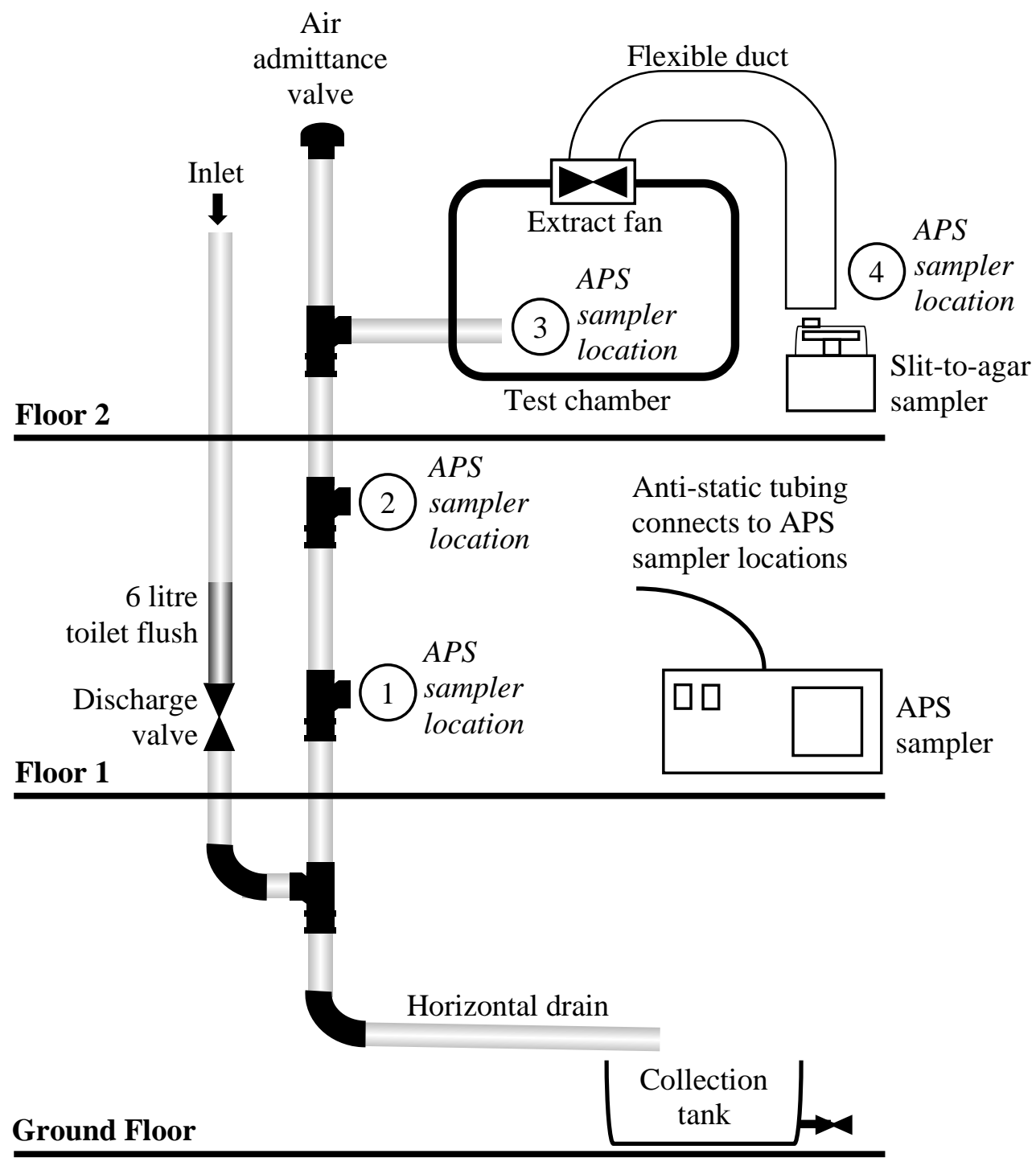

164 Figure 3: Building drainage system test-rig designed to BS EN12056:2000-2 ${ }^{27}$

167 The discharge flow profile of a 6 litre drop valve toilet is shown in Figure 4. The flush event 168 can be seen to last no more than 10 seconds. The fluid from the flush enters the vertical stack 169 of the sanitary plumbing system and falls creating an annular flow. The shear between the water 170 and the air causes an airflow to be entrained, thus causing air pressure fluctuations as the system 
medRxiv preprint doi: https://doi.org/10.1101/2020.11.01.20223974; this version posted November 4, 2020. The copyright holder for this preprint (which was not certified by peer review) is the author/funder, who has granted medRxiv a license to display the preprint in All rights reserved. No reuse allowed without permission.

171 attempts to balance airflow and pressure. The dynamics of this air intake follow the same pattern

172 as the toilet discharge flow profile. The turbulence caused by the air/water mixture as they

173 interact is sufficient to produce aerosols within the sanitary plumbing system. If the discharging

174 wastewater contains pathogenic micro-organisms, then bioaerosols can be generated that can

175 be transported on internal airflows.

176

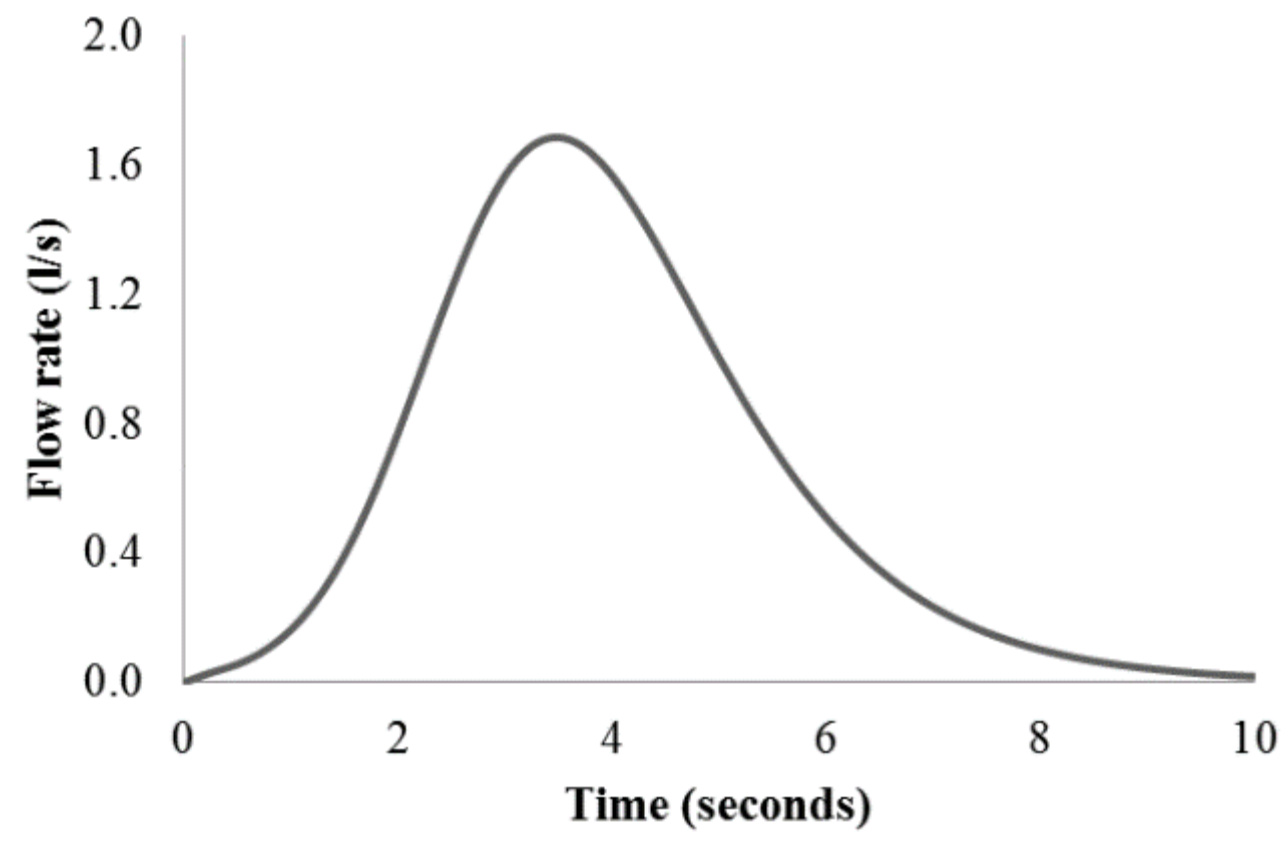

177

Figure 4: Discharge flow profile of a typical drop valve toilet

179

180

2.2 Airflow

181 Since the test rig was in a laboratory (and not connected to a complete sanitary plumbing system

182 or main sewer network) it was necessary to induce an updraught airflow using an extractor fan

183 in the test chamber. The airflow rates used were defined previously ${ }^{22}$ and were set to three

184 broad ranges:

185

- Low flow rate $(\sim 3 \mathrm{l} / \mathrm{s})$

186

- Medium flow rate $(\sim 5 \mathrm{l} / \mathrm{s})$

187

- High flow rate (>6 1/s ) 
medRxiv preprint doi: https://doi.org/10.1101/2020.11.01.20223974; this version posted November 4, 2020. The copyright holder for this preprint (which was not certified by peer review) is the author/funder, who has granted medRxiv a license to display the preprint in

All rights reserved. No reuse allowed without permission.

189 This ensured that results could be compared if they fell within the same range and ensured that

190 flow rates were representative of those found in real systems.

191

192

\subsection{Tracer organism}

193 The class 1 , non-genetically modified bacterium P. putida KT2440 ${ }^{28}$ was used as a tracer

194 organism. Pure colonies were picked from agar plates, inoculated into Erlenmeyer flasks containing tryptone soya broth and incubated overnight at $30^{\circ} \mathrm{C}$ with an orbital shaking. The resulting stock culture was diluted to achieve an optical density at $600 \mathrm{~nm}$ wavelength $\left(\mathrm{OD}_{600}\right)$ of 1.0 in $0.85 \%(\mathrm{w} / \mathrm{v}) \mathrm{NaCl}$ to provide an inoculum for the sanitary plumbing system

198 (corresponding to $\sim 10^{6} \mathrm{cfu} \mathrm{m}^{-1}$ ) forming the toilet flush volume.

199

\subsection{Aerosol and bioaerosol monitoring}

201 Two methods were used to sample and analyse the air particles emitted from the defective 202 sanitary plumbing system: i) Aerodynamic Particle Sizing (APS); and ii) Slit-to-agar air 203 sampling

An APS device (model 3321, TSI Inc., Shoreview, MN) was used to enumerate the particle

207 sizes of the air emitted from the test rig. The APS device was set to sample for 60 seconds 208 before the airflow was initiated and the toilet flush was discharged. Samples were taken from 209 the main vertical stack (APS sampler locations 1, 2, and 3 in Figure 3) and at the ductwork exit 210 (APS sampler location 4 in Figure 3). Each test was set to record data for approximated 500 211 seconds. The data was recorded and processed to give time stamped recordings of specific 212 particle sizes and the results graphed for inspection and analysis. 
medRxiv preprint doi: https://doi.org/10.1101/2020.11.01.20223974; this version posted November 4, 2020. The copyright holder for this preprint (which was not certified by peer review) is the author/funder, who has granted medRxiv a license to display the preprint in

All rights reserved. No reuse allowed without permission.

ii) Slit-to-agar sampler

215 A slit-to-agar air sampler (220 model; Mattson-Garvin) was setup at the end of the ductwork

216 exit to monitor viable bioaerosols. The sampler was installed with the manufacturers' 5 minute

217 motor and set to sample at a flow rate of 65 standard cubic feet per minute (SCFM).

219 Before each experiment, the sampler plate housing and slit inlet were sterilised with 95\% 220 ethanol. A single $150 \mathrm{~mm}$ diameter Pseudomonas Isolation Agar (PIA) plate was placed on the 221 rotor platform and secured with adhesive tape to prevent slippage. The height from plate to the 222 slit was adjusted as required to allow for differences in agar thickness.

224 The sampler was set to run for 60 seconds before the toilet flush was discharged. The sampler was then allowed to run for a total of 300 secs per experiment. After the experiments, the PIA plates were incubated for $24 \mathrm{~h}$ at $30^{\circ} \mathrm{C}$ before imaging and image analysis.

\subsection{Image analysis}

229 Images (.tiff format) of the slit-to-agar plates were opened in the image processing software 230 ImageJ (http://imagej.nih.gov/ij). The angle tool was used to determine the time location of 231 each individual colony.

\subsection{Experimental procedure}

234 The experimental procedure for both of these methods can be summarised as follows:

235 1. The system was washed down with biochlor ${ }^{\circledR}$ solution and rinsed with tap water

236 2. The 'inoculum' was loaded into the valve controlled discharge pipe

237 3. The induced airflow was initiated and allowed to stabilise 
medRxiv preprint doi: https://doi.org/10.1101/2020.11.01.20223974; this version posted November 4, 2020. The copyright holder for this preprint (which was not certified by peer review) is the author/funder, who has granted medRxiv a license to display the preprint in perpetuity.

All rights reserved. No reuse allowed without permission.

238 4. The sampler (APS or slit-to-agar) was turned on and allowed to run for at least 60 seconds

239 5. The flush valve was opened to allow the 'inoculum' to discharge into the vertical stack

240 Results were recorded in the APS, and for the slit-to-agar sampler, the PIA plate was marked

241 up and taken for incubation

242 A range of 'inocula' were used to establish the importance of different factors. Table 2 shows

243 the range of tests carried out.

Table 2: Experiments carried out

\begin{tabular}{|c|c|c|c|}
\hline $\begin{array}{l}\text { Experiment } \\
\text { type }\end{array}$ & Inoculum Description & Comments & $\begin{array}{l}\text { No. of experimental } \\
\text { test runs carried out }\end{array}$ \\
\hline A & No flush and no induced airflow & $\begin{array}{l}\text { Control test for APS background for } \\
\text { system at rest condition. }\end{array}$ & 1 \\
\hline B & Tap water only & Building water from a tank & 6 \\
\hline $\mathrm{C}$ & $\mathrm{NaCl}$ and tap water & Tap water with $0.85 \% \mathrm{NaCl}$ & 11 \\
\hline $\mathrm{D}$ & $\begin{array}{l}\text { De-ionised water, } \mathrm{NaCl} \text {, and } \\
\text { bacteria }\end{array}$ & $\begin{array}{l}\text { Inoculum of de-ionised water and } \\
\text { tracer organism (P. putida) }\end{array}$ & 12 \\
\hline$E$ & De-ionised water & $\begin{array}{l}\text { To test for particle sizes with no } \\
\text { impurities in water }\end{array}$ & 3 \\
\hline $\mathrm{F}$ & Water and Biochlor & Drain cleaning & 1 \\
\hline
\end{tabular}

Total

\section{Results}

\subsection{Aerosols / particles}

250 APS results were compiled for all the tests carried out and analysed for: (i) total concentration

251 of all particles (number of particles $/ \mathrm{cm}^{3}$ ); (ii) total number of particles per second; (iii) 
medRxiv preprint doi: https://doi.org/10.1101/2020.11.01.20223974; this version posted November 4, 2020. The copyright holder for this preprint (which was not certified by peer review) is the author/funder, who has granted medRxiv a license to display the preprint in All rights reserved. No reuse allowed without permission.

distribution of particle sizes in the air samples taken at each sampler location; (iv) variation of particle size distribution at the different sampler locations; and (v) effect of flush water volume on particle size distribution.

\subsubsection{Single Flush}

An example of the total number of particles per second emitted, and their concentration, for a

typical test is shown in Figure 5. The figure shows the results of Experiment D, where the toilet can clearly be seen.
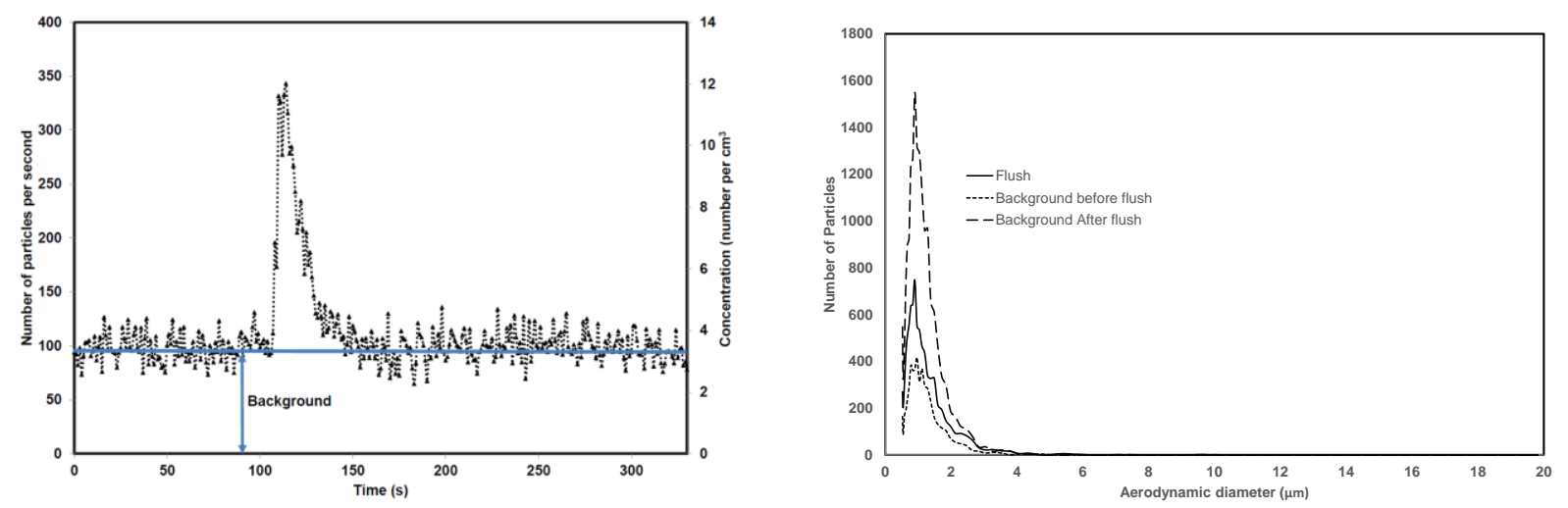

277 The peak of the induced spike was 245 particles/second at a concentration of 9 particles $/ \mathrm{cm}^{3}$ 278 (normalised without background). An average background particle level of 87 particles/second 
medRxiv preprint doi: https://doi.org/10.1101/2020.11.01.20223974; this version posted November 4, 2020. The copyright holder for this preprint (which was not certified by peer review) is the author/funder, who has granted medRxiv a license to display the preprint in All rights reserved. No reuse allowed without permission.

279 was also observed. Analysis of particle sizes show that $99.5 \%$ of all particles have an 280 aerodynamic diameter $\leq 5 \mu \mathrm{m}$.

\subsubsection{Background analysis (multiple consecutive flushes)}

282 Figure 5 illustrates that there was a considerable number of particles in the background before 283 the flush was initiated and an even greater number $\leq 5 \mu \mathrm{m}$ after the flush event. While this is 284 most likely due to the nature of the environment and operation of fans, movement of people 285 may also have caused increased activity. In order to test the continued generation of background 286 particles in the air, a three flush experiment was initiated using deionised water to reduce 287 impurities in the system (one of the Experiment $\mathrm{E}$ tests as detailed in Table 2 above, and measured at APS sampler location 4 as detailed in Figure 3 above). The result is shown in Figure 6 below. 


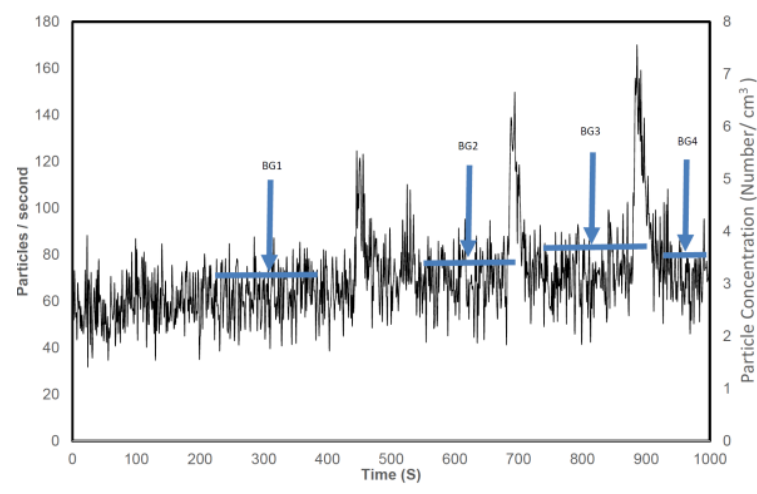

(A)

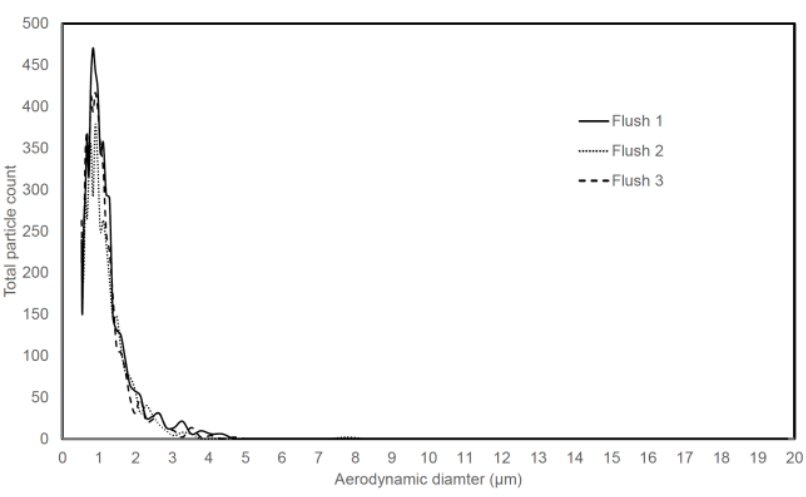

(B)

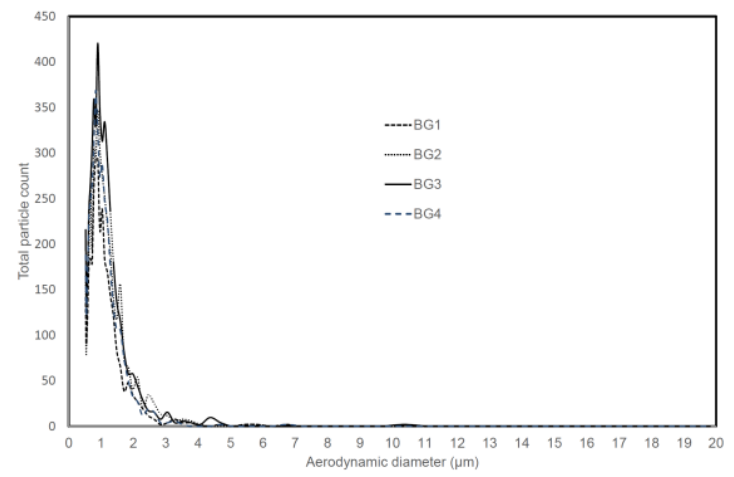

(C)

Figure 6: (A) Particle count and concentration for 3 consecutive flushes (de-ionised water) $(B)$ size distribution for the particles emitted during the flush and $(C)$ shows the size distribution for the background particles before and between flushes. (all background samples were for 53 seconds)

\subsubsection{Location of sampling}

To establish if the characteristics of the particle emissions (particularly size distribution) locations (APS sampler locations 1-4 as detailed in Figure 3 above). The results of the size distributions are shown in Figure 7 below. 
medRxiv preprint doi: https://doi.org/10.1101/2020.11.01.20223974; this version posted November 4, 2020. The copyright holder for this preprint (which was not certified by peer review) is the author/funder, who has granted medRxiv a license to display the preprint in All rights reserved. No reuse allowed without permission.

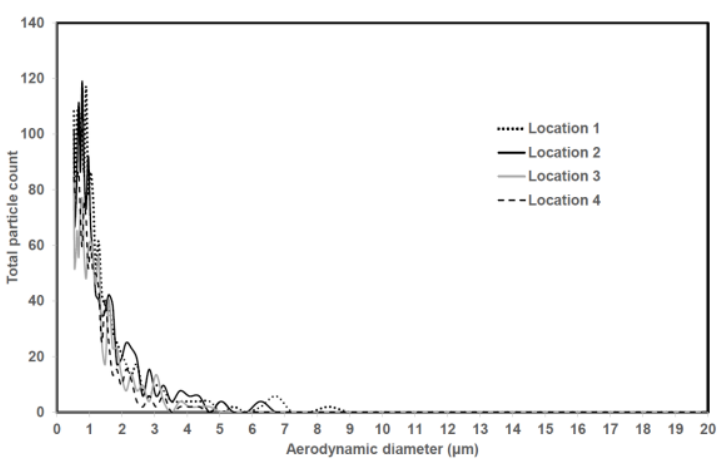

Figure 7: Particle size distribution at APS sampler locations 1-4 (see Figure 3). APS sampler location 1 is closest to the toilet flush and APS sampler location 4 furthest from the toilet

331 flush.

333 The particle size distribution at each of the four APS sampler locations can be seen to follow

334 the same general form of a single flush profile with the majority of particles being $\leq 5 \mu \mathrm{m}$ in 335 size, with only a very small number of larger diameter particles $(>5 \mu \mathrm{m})$. There were no particles 336 with an aerodynamic diameter greater than $9 \mu \mathrm{m}$ detected in the system following the toilet 337 flush and none greater than $11 \mu \mathrm{m}$ in the background data. (the particle size limit of the system 338 being $20 \mu \mathrm{m})$

\subsubsection{Flush Volume}

341 Most of the tests were carried out using a simulated toilet flush volume of 6 litres. An additional

342 set of experiments were carried out using a reduced volume to see the impact on aerosol 343 generation, Figure 8 below shows the results. 
medRxiv preprint doi: https://doi.org/10.1101/2020.11.01.20223974; this version posted November 4, 2020. The copyright holder for this preprint (which was not certified by peer review) is the author/funder, who has granted medRxiv a license to display the preprint in All rights reserved. No reuse allowed without permission.

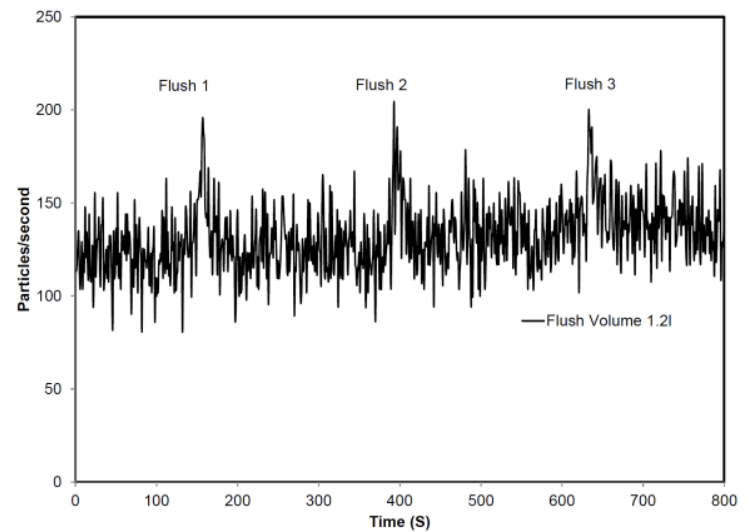

(A)

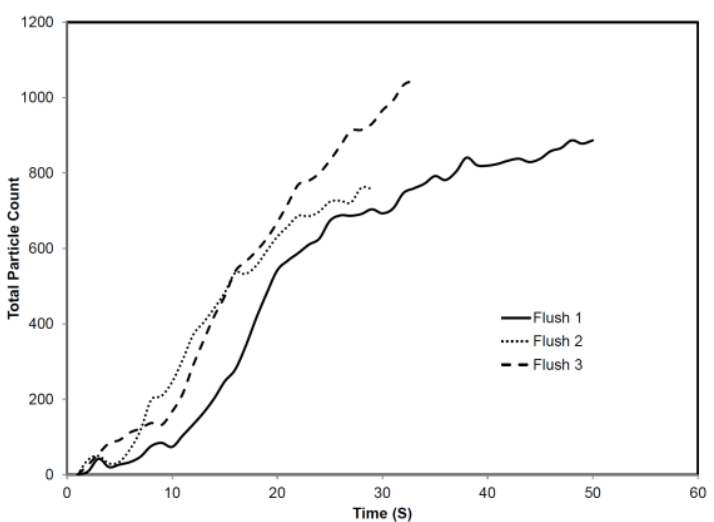

(B)

347 Figure 8: Particle results for reduced flush volume (1.2l) The spikes associated with each flush 348 are shown in (A) with an average normalised peak emissions of 73 particles/second. 349 Cumulative emissions for the three flushes are shown in (B) with cumulative emissions between 758 and 1045 particles.

\subsection{Viable bioaerosol dynamics}

353 An example slit-to-agar PIA plate after incubation is shown in Figure 9. The colonies start 354 appearing a short time after the flush is initiated. This time is determined by the delay between turning on the slit-to-agar sampler and the initiation of the toilet flush and the time taken for the tracer organism to travel from the discharge point to the slit-to-agar sampler, approximately 10 metres. The pattern of colonies shows clustering at the beginning, shortly after the flush is

358 initiated with a tailing off until the event ceases to contribute further tracer organism. An analysis of the kinetics of viable quantities of the tracer organism is given below. 


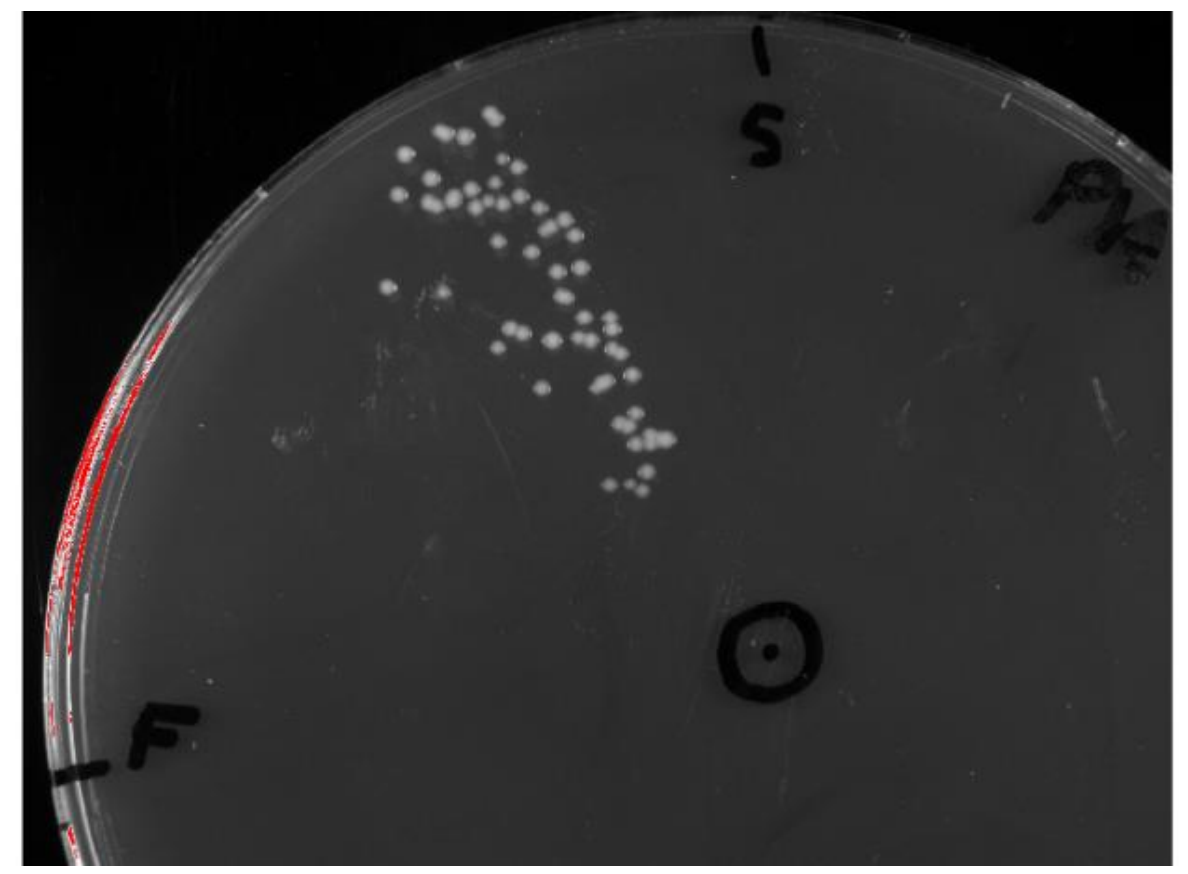

362 Figure 9: Image of $150 \mathrm{~mm}$ diameter PIA plate taken from the slit-to-agar sampler

363 (Experiment type D). Start $(S)$ and finish $(F)$ of 5 min sampling indicated.

365 Analysis of one slit-to-agar plate is presented in Figure 10. The toilet flush, instigated at 60 366 seconds, lasted for approximately 10 seconds (see Figure 4 above). The highest numbers of 367 CFUs can be seen to exit the ducting between 75 and 90 seconds (15-30 seconds after the toilet 368 flush). The number of CFUs then tail off and stop around 140 seconds (80 seconds after the 369 flush) A summary of all the experiments carried out is shown in Table 3. In addition to the CFU 370 data, an estimate of the velocity of the tracer organism in the system is given. This is based on 371 the time from the flush peak to the time the peak CFUs occurred. It can be seen that the tracer 372 organism velocity is much lower than the air velocity. 
medRxiv preprint doi: https://doi.org/10.1101/2020.11.01.20223974; this version posted November $4,2020$. The copyright holder for this preprint (which was not certified by peer review) is the author/funder, who has granted medRxiv a license to display the preprint in

All rights reserved. No reuse allowed without permission.

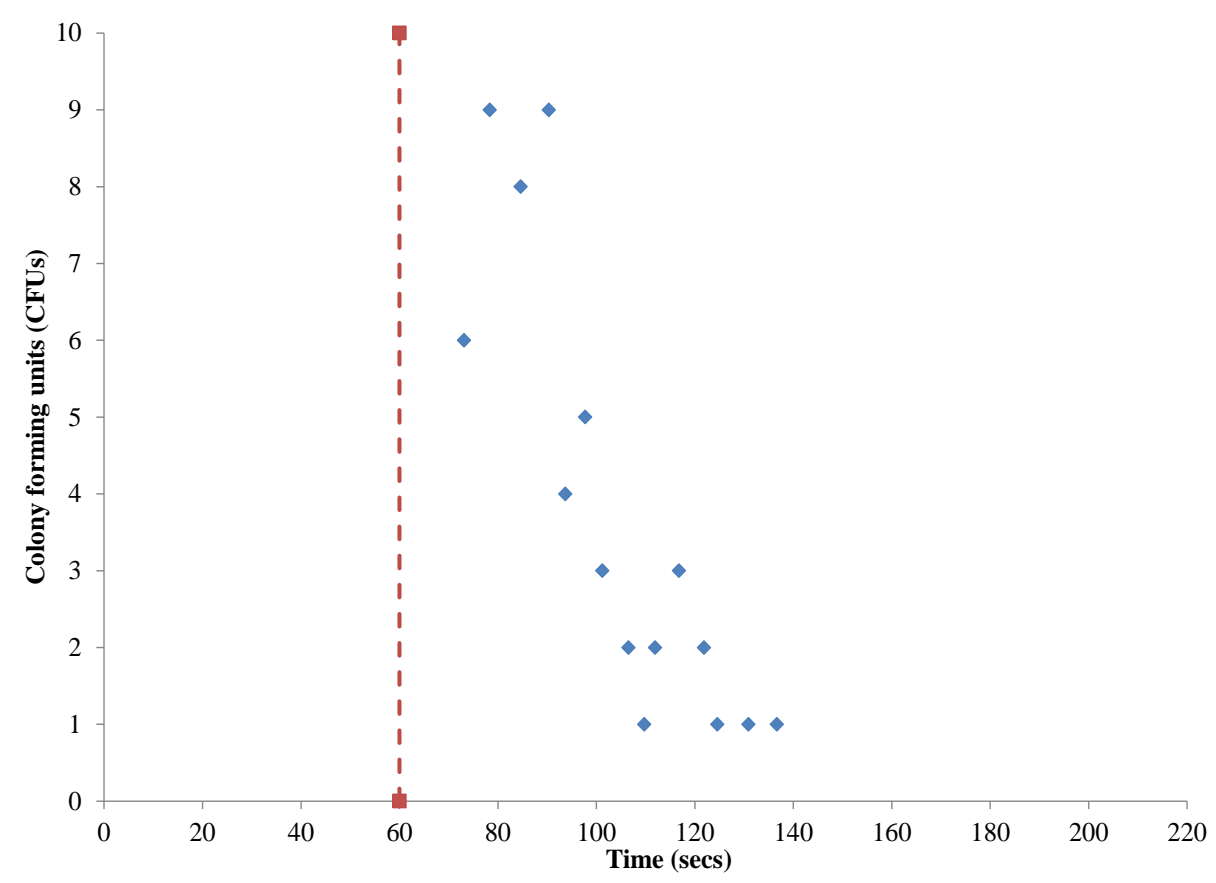

374

375 Figure 10: Example CFUs against time for a D type experiment

376 Table 3: Summary of experimental results on bacteria transport mechanisms

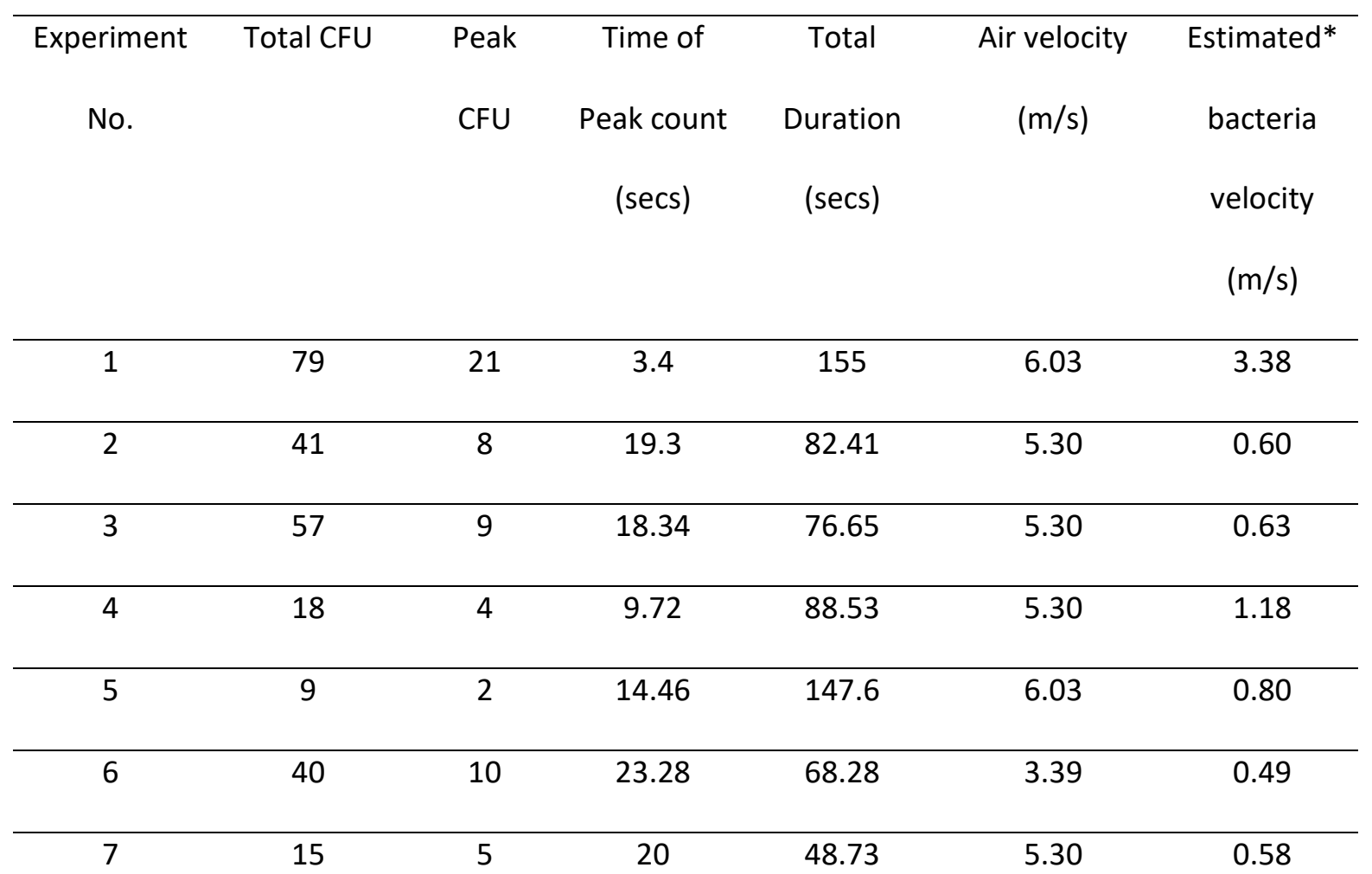

* Bacteria velocity is an estimate based on the time from the flush peak to the time the peak 378 CFUs occurred. 
medRxiv preprint doi: https://doi.org/10.1101/2020.11.01.20223974; this version posted November 4, 2020. The copyright holder for this preprint (which was not certified by peer review) is the author/funder, who has granted medRxiv a license to display the preprint in

All rights reserved. No reuse allowed without permission.

\section{DISCUSSION}

\subsection{General}

382 The results of the slit-to-agar method (Experiment D) show that a tracer organism flushed into

383 the sanitary plumbing system can be detected in the extract duct of a room on the level above

384 that of the contaminant input level within a building. The APS data shows a profile consistent 385 with the shape of the initiating toilet flush, but over a longer period of time. Typically, a 10

386 second toilet flush event was found to result in aerosols being emitted into the building over 60 387 seconds, however, this was found to range from 30-110 seconds in duration. This profile is 388 repeated in the slit-to-agar results for the tracer organism, with a characteristic sharp rise in 389 numbers followed by a longer tail off.

391 Although slit-to-agar samplers are typically used to quantify viable microorganisms within a given volume of air and are generally used for clean room and production area contamination

393 monitoring ${ }^{29,30}$, more recently they have found application for more general indoor air and

394 environmental monitoring ${ }^{31,32}$. Here, we show the novel application of a slit-to-agar sampler to 395 determine the kinetics of viable cells transported in the airstream through a building's sanitary 396 plumbing system. The sampler effectively determined a $\sim 15$ second time window when the 397 highest number of cells went through the system, followed by a tail of decreasing cell numbers 398 with time. This pattern in terms of peak and tails time was consistent across replicate 399 experiments and with different air flow rates. The CFUs measured at the system exit ranged in 400 duration between 48 seconds and 155 seconds.

402 When higher flow rates were used we found the same peak and tail patterns, however, isolated 403 colonies also appeared 140 seconds after the toilet flush on more than one occasion. We believe 
medRxiv preprint doi: https://doi.org/10.1101/2020.11.01.20223974; this version posted November 4, 2020. The copyright holder for this preprint (which was not certified by peer review) is the author/funder, who has granted medRxiv a license to display the preprint in All rights reserved. No perpetuity.

404 this was the result of cells detaching from within the sanitary plumbing system due to shear 405 stress under this higher air flow rate.

407 In our experiments, the slit-to-agar sampler was used as a semi-quantitative manner. The reason 408 for this was that the air flow rates within the sanitary plumbing system were in excess of the 409 sampling rate of the sampler. In addition, the duct outlet was larger than the inlet of the sampler and designed as such so as not to restrict airflow within the sanitary plumbing system. The 411 results obtained from the slit-to-agar sampling are indicative of the spatial and temporal 412 distribution of viable bacteria into the building from the sanitary plumbing system. While this 413 serves as semi-quantitative data, there is evidence that slit-to-agar sampling underestimates the 414 number of bacteria against other methods 33

\subsection{APS Results in Context}

417 In order to establish an equivalence with a known source of bioaerosol infection emission, we 418 adapted data from Asadi et al., ${ }^{34}$ who investigated particle emissions from people talking 419 loudly. Asadi's team asked subjects to talk loudly into a particle sampler to capture the magnitude, concentration and particle size distribution from a test speech involving talking 421 loudly followed by periods of breathing only. We adapted this data to show the cumulative emissions from talking loudly for 120 seconds. This is shown in Figure 10 . We also plotted the cumulative emissions from our Experiment D which used 6 litres as the toilet flush volume, and

424 measured at APS sampler location 4. By extending the trendline on the Asadi data we can see that the number of particles emitted from the sanitary plumbing system as a result of a toilet flush is equivalent to a person talking loudly for 404 seconds (or just over 6 and a half minutes). 
medRxiv preprint doi: https://doi.org/10.1101/2020.11.01.20223974; this version posted November 4, 2020. The copyright holder for this preprint (which was not certified by peer review) is the author/funder, who has granted medRxiv a license to display the preprint in All rights reserved. No reuse allowed without permission.

Figure 11: Equivalence between particles emitted as a result of a toilet flush in a sanitary

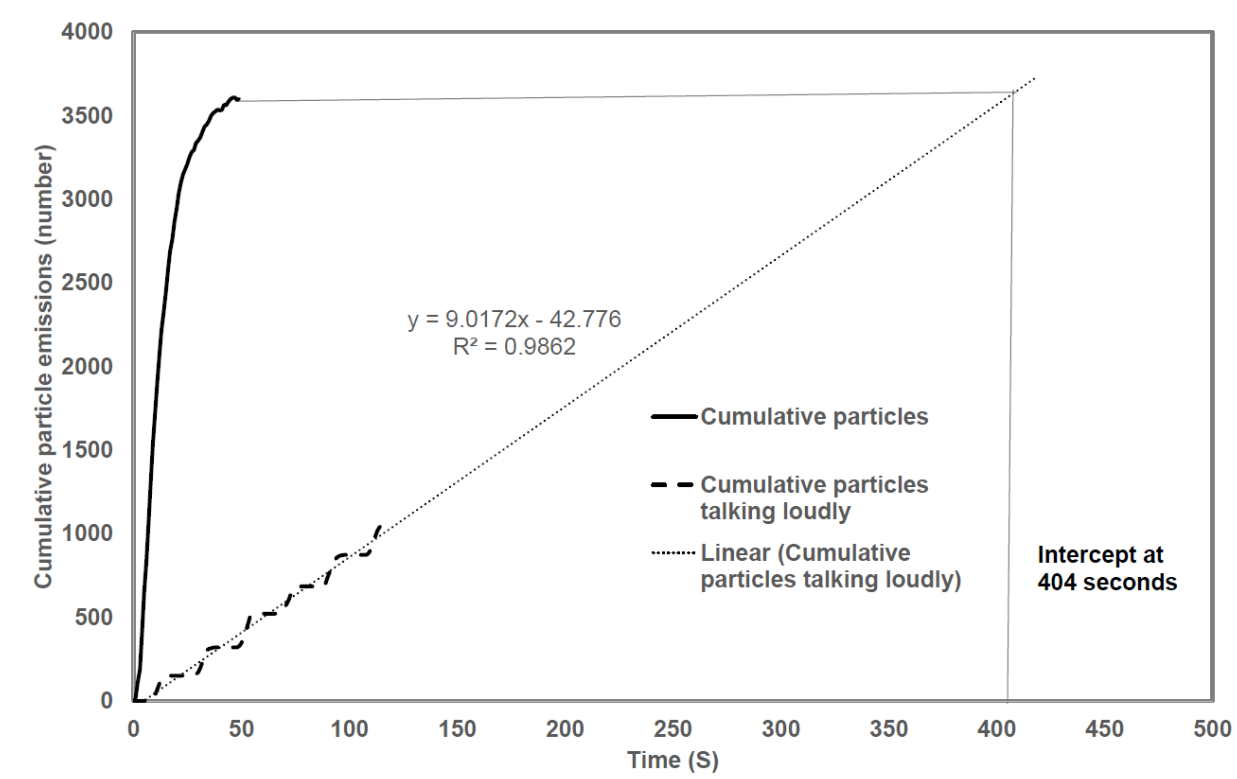

\section{CONCLUSIONS}

443 The experiments show that the generation and transport of aerosols and a tracer organism, $P$.

444 putida KT2440, within a sanitary plumbing system are determined by the unsteady 445 characteristics of the air and water flows within the system itself. The pattern of particles recorded by APS and the bacteria cultured on the PIA plates are consistent with the pattern of the toilet flush mechanism which initiates the inflow of the tracer organism into the system, and, sets up the turbulent conditions from which aerosolisation occurs.

The characteristics of the particles generated within the sanitary plumbing system following a

451 simulated toilet flush are almost entirely aerosols with an aerodynamic diameter $\leq 5 \mu \mathrm{m}$. There

452 were only a small number of particles between 10 and $11 \mu \mathrm{m}$ when measured nearer the source.

453 Over $99.5 \%$ of all particles were $<5 \mu \mathrm{m}$ in diameter. These characteristics mean that aerosols 454 and bioaerosols from a sanitary plumbing system are amenable to be carried long distances on airflows inside buildings. We assume that larger droplets were generated but were not carried 
medRxiv preprint doi: https://doi.org/10.1101/2020.11.01.20223974; this version posted November 4, 2020. The copyright holder for this preprint (which was not certified by peer review) is the author/funder, who has granted medRxiv a license to display the preprint in

All rights reserved. No reuse allowed without permission.

on the airflow and were deposited on pipe walls and in the chamber. The total number of particles emitted by the system into the room has been shown to be the equivalent of a person taking loudly for approximately 6 and a half minutes.

Particle count was influenced by flush volume, but it was not possible to determine if there was any direct influence from airflow rate, although it may have had some effect on the duration of the emission. A wider range of airflow rate would be required to verify this. Typical emissions resulting from a 6 litre flush was in the range $280-400$ particles per second at a concentration of typically 9 to 12 number per $\mathrm{cm}^{3}$ and a total particle count in the region of 3,000 to 4,000 particles, whereas the peak emissions from a 1.2 litre flush was 60 - 80 particles per second at a concentration of 2.4 to 3 number per $\mathrm{cm}^{3}$ and a total particle count in the region of 886 to 1045 particles. The reduction in particles is in direct proportion to the reduction in flush volume.

The event-causing bioaerosols in these experiments was a simulated toilet flush containing the P. putida KT2440 tracer organism at a dose rate of $\sim 10^{6} \mathrm{cfu} \mathrm{m}^{-1}$. This event lasted no more than 10 seconds. The discharge of the toilet flush into the sanitary plumbing system instigated an aerosolisation process due to the turbulent flow conditions. The resulting CFUs measured at the system exit ranged in duration between 48 seconds and 155 seconds. The pattern of CFU on the slit-to-agar sampler PIA plates confirms that the tracer organism concentration followed the flush characteristic (in litres/sec), the elongation of the surge wave being attributable to the difference in velocity between the bioaerosols and the air.

This work highlights the complexity of tracking and quantifying aerosols and bioaerosol transmission due to short-burst events such as those found in sanitary plumbing systems. The current COVID-19 pandemic has emphasised the challenges for all building systems in 
medRxiv preprint doi: https://doi.org/10.1101/2020.11.01.20223974; this version posted November 4, 2020. The copyright holder for this preprint (which was not certified by peer review) is the author/funder, who has granted medRxiv a license to display the preprint in

All rights reserved. No reuse allowed without permission.

481 maintaining healthy indoor environments and highlights the consequences of ignoring potential

482 disease transmission routes.

483

484

\section{ACKNOWLEDGEMENT}

485

This research was funded by the School of Energy, Geoscience, Infrastructure and Society

486 research seed-corn fund at Heriot-Watt University

487

\section{CONFLICT OF INTEREST}

489

The authors declare no conflict of interest.

\section{AUTHOR CONTRIBUTIONS}

495

All authors contributed equally to the design, collection and analysis of the data. MG secured 496 the funding and all authors contributed equally to the preparation of the manuscript.

498 1. Zhu N, Zhang D, Wang W, et al. A novel coronavirus from patients with pneumonia in China, 2019. N Engl J Med. 2020;382(8):727-733. doi:10.1056/NEJMoa2001017

2. Morawska L, Milton DK. It is Time to Address Airborne Transmission of COVID-19. Clin Infect Dis. July 2020. doi:10.1093/cid/ciaa939

3. Morawska L. Droplet fate in indoor environments, or can we prevent the spread of infection? Indoor Air. 2006;16(5):335-347. doi:10.1111/j.1600-0668.2006.00432.x

4. van Doremalen N, Bushmaker T, Morris DH, et al. Aerosol and Surface Stability of SARS-CoV-2 as Compared with SARS-CoV-1. N Engl J Med. 2020;382(16):1564-1567. doi:10.1056/NEJMc2004973

5. Stetzenbach LD, Buttner MP, Cruz P. Detection and enumeration of airborne 
medRxiv preprint doi: https://doi.org/10.1101/2020.11.01.20223974; this version posted November 4, 2020. The copyright holder for this preprint (which was not certified by peer review) is the author/funder, who has granted medRxiv a license to display the preprint in All rights reserved. No reuse allowed without permission.

510 6. Wong KC, Leung KS. Transmission and Prevention of Occupational Infections in

511

512

513

Orthopaedic

Surgeons.

$J B J S$. 2004;86(5). https://journals.lww.com/jbjsjournal/Fulltext/2004/05000/Transmission_and_Preventio n_of_Occupational.29.aspx.

7. Atkinson J, Chartier Y, Pessoa-Silva CL, Jensen P, Li Y, Seto W-H, eds. Natural Ventilation for Infection Control in Health-Care Settings. WHO Geneva; 2009.

8. Hambach R, Droste J, François G, et al. Work-related health symptoms among compost facility workers: a cross-sectional study. Arch Public Health. 2012;70(1):13. doi:10.1186/0778-7367-70-13

9. Verani M, Bigazzi R, Carducci A. Viral contamination of aerosol and surfaces through toilet use in health care and other settings. Am J Infect Control. 2014;42(7):758-762. doi:10.1016/j.ajic.2014.03.026

10. Best EL, Sandoe JAT, Wilcox MH. Potential for aerosolization of Clostridium difficile after flushing toilets: The role of toilet lids in reducing environmental contamination risk. J Hosp Infect. 2012;80(1):1-5. doi:10.1016/j.jhin.2011.08.010

11. Johnson D, Lynch R, Marshall C, Mead K, Hirst D. Aerosol generation by modern flush toilets. Aerosol Sci Technol. 2013;47(9):1047-1057. doi:10.1080/02786826.2013.814911

12. Gormley M, Kelly DA, Aspray TJ. Bio-aerosol cross-transmission via the building drainage system. In: Indoor Air 2014 - 13th International Conference on Indoor Air Quality and Climate. ; 2014.

13. Swaffield JA, Campbell DP, Gormley M. Pressure transient control: Part II - Simulation and design of a positive surge protection device for building drainage networks. Build Serv Eng Res Technol. 2005;26(3). doi:10.1191/0143624405bt120oa

14. Gormley M. Air pressure transient generation as a result of falling solids in building 
medRxiv preprint doi: https://doi.org/10.1101/2020.11.01.20223974; this version posted November 4, 2020. The copyright holder for this preprint (which was not certified by peer review) is the author/funder, who has granted medRxiv a license to display the preprint in

All rights reserved. No reuse allowed without permission.

drainage stacks: Definition, mechanisms and modelling. Build Serv Eng Res Technol. 2007;28(1). doi:10.1177/0143624406071980

15. Gormley M, Kelly DA. Pressure transient suppression in drainage systems of tall buildings. Build Res Inf. 2018. doi:10.1080/09613218.2017.1412097

16. Gormley M. Can numerical computer modelling aid innovation, efficiency and cost reduction in sanitation provision? Desalination. 2009;248(1-3):286-290. doi:10.1016/j.desal.2008.05.067

17. Swaffield J. Transient Airflow in Building Drainage Systems. London: Spon; 2010.

18. Ling Y, Xu S-B, Lin Y-X, et al. Persistence and clearance of viral RNA in 2019 novel coronavirus disease rehabilitation patients. Chin Med J (Engl). 2020;133(9). https://journals.lww.com/cmj/Fulltext/2020/05050/Persistence_and_clearance_of_viral _RNA_in_2019.6.aspx.

19. Lee N, Yuen KY, Sung JJY. Enteric Involvement of Severe Acute Respiratory Syndrome -. Gastroenterology. 2003;5085(03):1011-1017. doi:10.1053/S0016-5085(03)01215-0

20. Kang M; $Z$ et al. Probable Evidence of Fecal-Respitory Transmission of SARS-CoV-2 in a high-rise building. Ann Intern Med. 2020.

21. Gormley M, Templeton KE, Kelly DA, Hardie A. Environmental conditions and the prevalence of norovirus in hospital building drainage system wastewater and airflows. Build Serv Eng Res Technol. 2014;35(3). doi:10.1177/0143624413485080

22. Gormley M, Aspray TJ, Kelly DA, Rodriguez-Gil C. Pathogen cross-transmission via building sanitary plumbing systems in a full scale pilot test-rig. PLoS One. 2017;12(2). doi:10.1371/journal.pone.0171556

23. WHO. Consensus document on the epidemiology of severe acute respiratory syndrome (SARS). 2003. 
medRxiv preprint doi: https://doi.org/10.1101/2020.11.01.20223974; this version posted November 4, 2020. The copyright holder for this preprint (which was not certified by peer review) is the author/funder, who has granted medRxiv a license to display the preprint in

All rights reserved. No reuse allowed without permission.

research into the causes of SARS virus transmission in a high-rise residential housing estate in Hong Kong. Build Serv Eng Res Technol. 2006;27(2):91-102. doi:10.1191/0143624406bt145oa

25. McKinney KR, Gong YY, Lewis TG. Environmental transmission of SARS at Amoy Gardens. J Environ Health. 2006;68(9):26-30.

26. Gormley M, Swaffield JA, Sleigh PA, Noakes CJ. An assessment of, and response to, potential cross-contamination routes due to defective appliance water trap seals in building drainage systems. Build Serv Eng Res Technol. 2012;33(2). doi:10.1177/0143624411410619

27. BSI. BS EN 12056-2:2000 Gravity Drainage Systems inside Buildings. Sanitary Pipework, Layout and Calculation British Standards Institute.; 2000.

28. Gormley M, Aspray TJ, Kelly DA. COVID-19: mitigating transmission via wastewater plumbing systems. Lancet Glob Heal. 2020;8(5):e643. doi:10.1016/S2214109X(20)30112-1

29. Temprano G, Garrido D, D\&\#039;Aquino M. Comparative Study of Airborne Viable Particles Assessment Methods in Microbiological Environmental Monitoring. PDA $J$

Pharm $S c i$ Technol. 2004;58(4):215 http://journal.pda.org/content/58/4/215.abstract.

30. Ho J, Stanley NJ, Kuehn TH. Feasibility of using real-time optical methods for detecting the presence of viable bacteria aerosols at low concentrations in clean room environments. Aerobiologia (Bologna). 2011;27(2):163-172. doi:10.1007/s10453-0109185-8

31. Blatny JM, Ho J, Skogan G, Fykse EM, Aarskaug T, Waagen V. Airborne Legionella bacteria from pulp waste treatment plant: aerosol particles characterized as aggregates and their potential hazard. Aerobiologia (Bologna). 2011;27(2):147-162. 
medRxiv preprint doi: https://doi.org/10.1101/2020.11.01.20223974; this version posted November 4, 2020. The copyright holder for this preprint (which was not certified by peer review) is the author/funder, who has granted medRxiv a license to display the preprint in All rights reserved. No reuse allowed without permission.

doi:10.1007/s10453-010-9184-9

586 32. Rojas TI, Aira MJ. Fungal biodiversity in indoor environments in Havana, Cuba. Aerobiologia (Bologna). 2012;28(3):367-374. doi:10.1007/s10453-011-9241-z

588 33. Placencia AM, Peeler JT, Oxborrow GS, Danielson JW. Comparison of bacterial recovery by Reuter centrifugal air sampler and slit-to-agar sampler. Appl Environ Microbiol. 1982;44(2):512 LP - 513. http://aem.asm.org/content/44/2/512.abstract.

591 34. Asadi S, Wexler AS, Cappa CD, Barreda S, Bouvier NM, Ristenpart WD. Aerosol emission and superemission during human speech increase with voice loudness. Sci Rep. 